\title{
IMECE2006-13597
}

\section{A Train-to-Train Impact Test of Crash Energy Management Passenger Rail Equipment: Structural Results}

\author{
David Tyrell \\ Karina Jacobsen \\ Eloy Martinez \\ Volpe National Transportation Systems Center \\ US Department of Transportation \\ Cambridge, MA 02142 USA
}

A. Benjamin Perlman

Tufts University

Medford, MA 02155 USA

\section{ABSTRACT}

On March 23, 2006, a full-scale test was conducted on a passenger rail train retrofitted with newly developed cab end and non-cab end crush zone designs. This test was conducted as part of a larger testing program to establish the degree of enhanced performance of alternative design strategies for passenger rail crashworthiness. The alternative design strategy is referred to as crash energy management (CEM), where the collision energy is absorbed in defined unoccupied locations throughout the train in a controlled progressive manner. By controlling the deformations at critical locations the CEM train is able to protect against two dangerous modes of deformation: override and large-scale lateral buckling.

The CEM train impacted a standing locomotive-led train of equal mass at $31 \mathrm{mph}$ on tangent track. The interactions at the colliding interface and between coupled interfaces performed as expected. Crush was pushed back to subsequent crush zones and the moving passenger train remained in-line and upright on the tracks with minimal vertical and lateral motions.

The added complexity associated with this test over previous full-scale tests of the CEM design was the need to control the interactions at the colliding interface between the two very different engaging geometries. The cab end crush zone performed as intended because the locomotive coupler pushed underneath the cab car buffer beam, and the deformable anti-climber engaged the uneven geometry of the locomotive anti-climber and short hood. Space was preserved for the operator as the cab end crush zone collapsed.

The coupled interfaces performed as predicted by the analysis and previous testing. The conventional interlocking anti-climbers engaged after the pushback couplers triggered and absorbed the prescribed amount of energy. Load was transferred through the integrated end frame, and progressive controlled collapsed was contained to the energy absorbers at the roof and floor level. The results of this full-scale test have clearly demonstrated the significant enhancement in safety for passengers and crew members involved in a push mode collision with a standing locomotive train.

\section{INTRODUCTION}

The Federal Railroad Administration (FRA), with assistance from the Volpe Center, has been conducting research on passenger rail equipment crashworthiness to develop technical information needed by FRA to promulgate passenger rail equipment safety regulations $[1,2,3]$. The principal focus of the passenger rail equipment crashworthiness research has been the development of structural crashworthiness and interior occupant protection strategies. The results of the research have also been used in the development of railroad procurement specifications $[4,5]$ and industry standards $[6,7]$.

\section{Background}

Cab car- and multiple unit (MU) locomotive-led trains present a challenging situation in collisions. The presence of passengers in lead vehicles of lighter weight and lower strength, in comparison with conventional locomotives, presents a potential hazard in the event of a collision. In order to address this exposure, FRA has conducted research on strategies intended to improve the crashworthiness of cab cars and MU locomotives $[8,9,10,11,12,13]$.

$\mathrm{Cab}$ cars, MU locomotives, and conventional coach cars must support an 800,000-pound longitudinal static load applied at the buff stops without permanent deformation. (See 49 C.F.R. 238.203 [3].) This requirement assures a minimum strength of the vehicle's occupied volume. The buff stops are 
located approximately 6 feet from the end of the vehicle and support the compressive longitudinal loads from the coupler, as seen schematically in Figure 1. Meeting this requirement using conventional design practices has resulted in structures that are nearly uniform in their axial strength. These structures are as strong at the ends as at the mid-length.
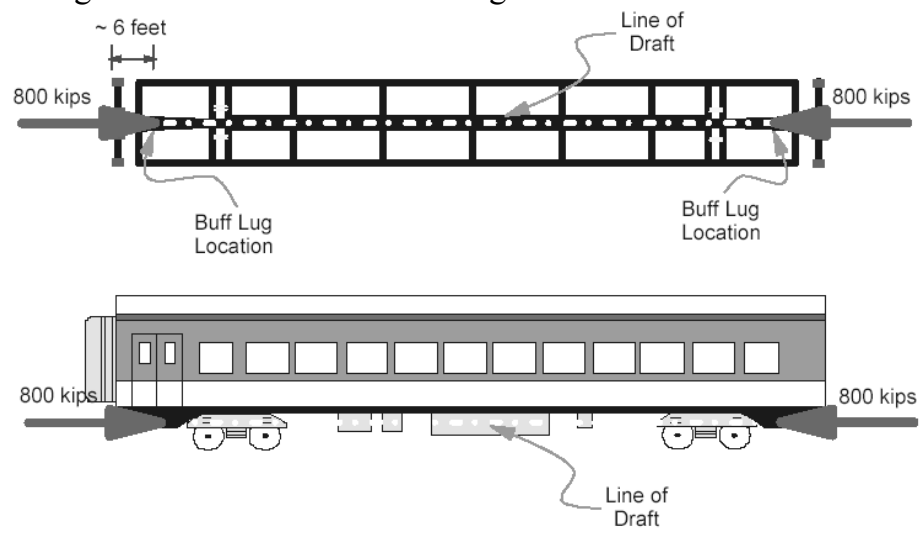

Figure 1. Schematic Illustration of Conventional Passenger Car

When a cab car, MU locomotive, or conventional coach car is loaded longitudinally, the structure of the vehicle's body is initially very stiff. As the load is increased, deflections of the vehicle body remain relatively small until a critical load is reached, and the body begins to cripple. Once crippled, its ability to further support a longitudinal load is compromised. As a result, a much lower load is required to deform the vehicle body longitudinally, and the deflections of the vehicle body increase significantly. This behavior is shown schematically as the conventional force/crush characteristic in Figure 2. Because the longitudinal force develops in the impacting cars first, once the peak force is attained and the vehicle body cripples, the colliding vehicle of a train will lose the ability to transmit significant longitudinal forces rearward to the trailing cars. In a collision, a colliding vehicle that performs in this manner will singularly absorb much of the collision energy as the occupied volume crushes. If the collision is extreme, this situation can result in the colliding vehicle being destroyed.

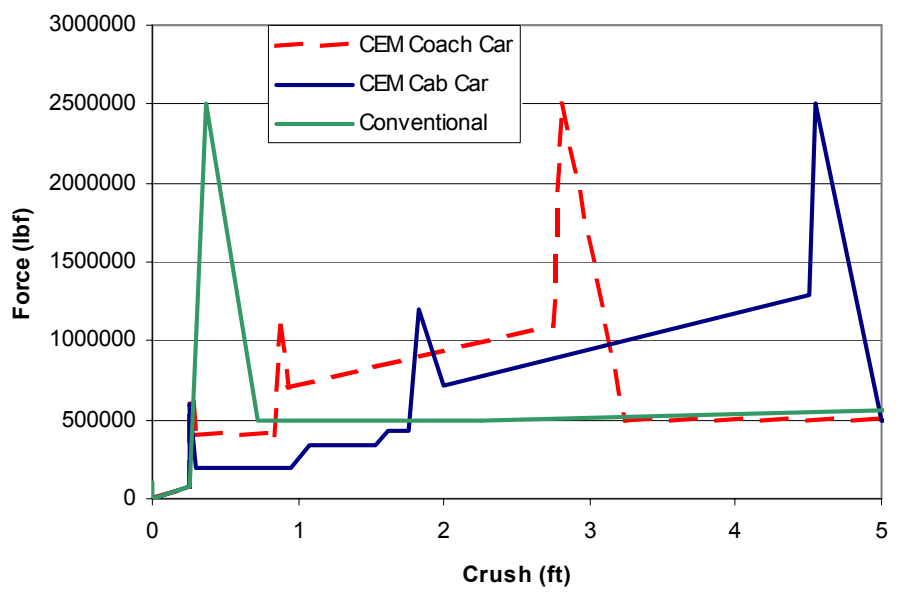

Figure 2. Idealized CEM Force/Crush Characteristics

Passenger rail equipment crashworthiness can be significantly increased if the force/crush behavior is engineered to take place in a controlled manner. Sacrificial crush zones can be designed into unoccupied locations in the rail vehicles, such as brake and electrical service closets and bicycle storage areas, as well lightly occupied areas, such as vestibules and stairwells. These crush zones are designed to crush gracefully, with a lower initial force and increased average force. Idealized coach and cab-end force/crush characteristics are shown in Figure 2. With such crush zones, multiple vehicles share energy absorption during the collision, consequently preserving the integrity of the occupied areas by managing the collision energy.

In cab cars and MU locomotives, measures are required to provide protection for the train operator, who is located closest to the impact in a train-to-train collision. One alternative is to move the operator back from the end of the cab car/MU locomotive, inboard of the crush zone. Interior measures similar to those used for the passengers can be employed to protect the operator. Another alternative is to keep the operator at the end of the cab car/MU locomotive, ahead of the crush zone. In this alternative, the operator's cab is surrounded by a structure that can slide back as the energy dissipation elements are crushed. The area behind the operator is unoccupied but could be used as a utility closet for brake or electrical equipment. This arrangement allows for preservation of the operator's volume in the event of a collision but exposes the operator to higher deceleration than the passengers. To protect the operator in this arrangement, additional measures, such as seatbelts, airbags, or other inflatable structures, may be necessary.

The approach of including crush zones is termed crash energy management (CEM). It extends from current conventional crashworthiness design practice; the 800,000pound buff strength requirement prescribes the strength of the structure that supports the crush zone. By doing so, current practice controls the force required for crushing the crush zone, which in turn influences the amount of energy absorbed. Greater buff strength allows greater crushing forces to be supported, and, in turn, greater energy can be absorbed for a given crush distance.

\section{In-Line Impact Tests}

FRA and Volpe have conducted six tests to measure the crashworthiness performance of existing equipment and to measure the performance of equipment incorporating CEM features. The collision scenario addressed by these tests is a cab car-led passenger train colliding with a conventional locomotive-led passenger train. The tests conducted for each equipment type include:

1. Single-car impact into a fixed barrier

2. Two coupled car impact into a fixed barrier

3. Cab car-led train collision with standing conventional locomotive-led train

The overall objectives of these tests are to demonstrate the effectiveness of:

- Improved crashworthiness cab car and MU locomotive structural designs

- Improved crashworthiness coach car structural designs

- A variety of interior occupant protection strategies 
This arrangement of the tests allows comparison of the existing equipment's performance with the performance of improved crashworthiness equipment. The sequence of impact tests allows an in-line train-to-train collision to be studied in incremental levels of complexity. These tests are intended to measure the crashworthiness of a single passenger car, then the interactions of two such cars when coupled, and finally the behavior of complete trains, including the interactions of the colliding cars. Table 1 summarizes the results of the conventional and CEM equipment in-line tests.

Table 1. Summary of In-line Test Results

\begin{tabular}{|l|l|l|l|}
\hline \multirow{2}{*}{$\begin{array}{l}\text { Test } \\
\text { Description }\end{array}$} & \multicolumn{1}{|c||}{ Critical Measurement } & \multicolumn{2}{c|}{ Results } \\
\cline { 3 - 4 } & & $\begin{array}{l}\text { Conventional } \\
\text { Equipment }\end{array}$ & CEM Equipment \\
\hline $\begin{array}{l}\text { Single-car } \\
\text { Test }\end{array}$ & $\begin{array}{l}\text { Occupant volume } \\
\text { Force-crush characteristic } \\
\text { Mode of deformation }\end{array}$ & $\begin{array}{l}\text { Loss } \\
\text { Decreasing } \\
\text { Ramp }\end{array}$ & $\begin{array}{l}\text { Increasing } \\
\text { Controlled }\end{array}$ \\
\hline $\begin{array}{l}\text { Two-car } \\
\text { Test }\end{array}$ & $\begin{array}{l}\text { Occupant volume } \\
\text { Interaction of coupled cars } \\
\text { Distribution of crush }\end{array}$ & $\begin{array}{l}\text { Loss } \\
\text { Sawtooth buckled } \\
\text { Focused on } \\
\text { impact car }\end{array}$ & $\begin{array}{l}\text { Remained in-line } \\
\text { Distributed }\end{array}$ \\
\hline $\begin{array}{l}\text { Train-to- } \\
\text { train Test }\end{array}$ & $\begin{array}{l}\text { Occupant volume } \\
\text { Colliding equipment interaction } \\
\text { Distribution of crush }\end{array}$ & $\begin{array}{l}\text { Ooss } \\
\text { Override } \\
\text { Focused on } \\
\text { impact car }\end{array}$ & $\begin{array}{l}\text { Preserved } \\
\text { Engagement }\end{array}$ \\
\hline
\end{tabular}

The results from these tests show that the CEM design has superior crashworthiness performance over existing equipment. In the single-car test of existing equipment [14] at a closing speed of $35 \mathrm{mph}$, the car was reduced in length by approximately 6 feet, with intrusion into the occupied area. The draft sill was crippled during the impact, with plastic deformation extending past the buff stops. Under the single-car test conditions at a closing speed of $34 \mathrm{mph}$, the CEM car crushed about 3 feet, preserving the occupied area. As a result of the controlled crush of the carbody structure, its wheels remained on the rails [15].

In the two-car test of existing equipment [16] at a closing speed of $26 \mathrm{mph}$, the impact car again crushed by approximately 6 feet. No crush of the trailing car occurred. The conventional couplers caused the cars to buckle laterally and derail. As a result of this misalignment of the coupled cars, the trucks immediately adjacent to the coupled connection derailed. In the two-car test of CEM equipment, at a closing speed of $29 \mathrm{mph}$, the cars preserved the occupant areas. The impact car crushed at the front and rear, and the trailing car crushed at the front. The pushback couplers allowed the cars to remain in-line with all of the wheels on the rails [17].
In the train-to-train test of existing equipment [18], at a closing speed of $30 \mathrm{mph}$, the colliding cab car crushed by approximately 22 feet. No crush was imparted to any of the trailing equipment. Due to the crippling of the cab car structure, the cab car overrode the conventional locomotive. The space for the operator's seat and for approximately 47 passenger seats was lost. During the train-to-train test of CEM equipment, at a closing speed of $31 \mathrm{mph}$, the front of the cab car crushed by approximately 3 feet. The controlled deformation of the cab car prevented override. All of the crew and passenger space was preserved.

While computer simulation models are not necessary to describe the results of the full-scale tests, they are critical to their conduct. Such models were used to determine the impact speed and measurements to be made, as well as to predict the behavior of the equipment during the test. In turn, these models have been refined using the test measurements. The results of the first three tests were especially useful in refining the models. For the fourth and subsequent tests, the pre-test predictions have been within the repeatability of the test. These models can then be used to predict the results of similar collision scenarios with varying initial conditions.

\section{TRAIN-TO-TRAIN TEST DESCRIPTION}

Figure 3 shows a schematic of the train-to-train impact test. In this test, a moving cab car-led train impacted a standing locomotive-led train. The locomotive-led train included two hopper cars, ballasted such that both trains weighed nearly the same. The impact locomotive was an EMD F40 compliant with the Association of American Railroads (AAR) S580 standard [7]. The cab car-led train included four passenger cars and a trailing locomotive. The passenger car consist is typical of a commuter push-pull consist with a locomotive at one end, leading away from a city, and a cab car at the other to lead into the city. The impact occurred on tangent track, with the cab car-led train initially traveling at $30.8 \mathrm{mph}$.

CEM end structures were installed at each end of each passenger car. The interfaces contacting a locomotive (front end of the lead cab car and the rear end of the car adjacent to the rear of the locomotive) had cab end crush zones that included such features as a deformable anti-climber, pushback operator's compartment, and crushable components.

Simulations of the test were conducted in order to verify that the CEM design would function as intended and to determine the size and placement requirements for the structural instrumentation. These simulations assured that the final crush zone designs limited the potential for override of the

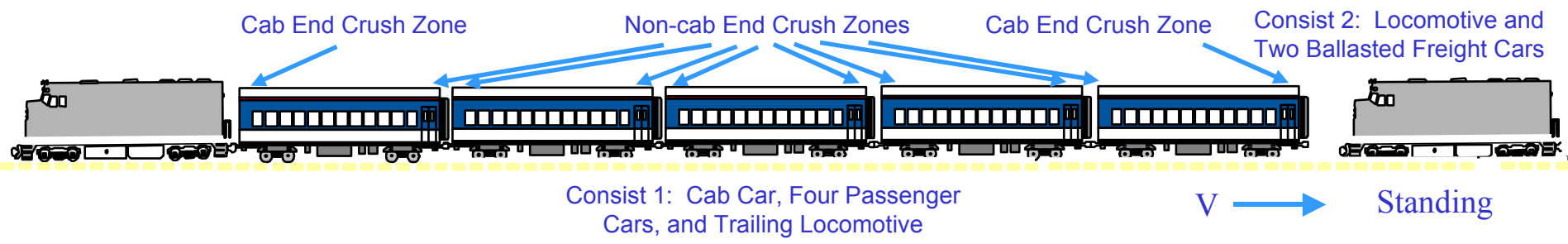

Figure 3. Schematic of Train-to-Train Test 
colliding equipment, and would be able to propagate the crush among all the train's cars. Instrumentation included accelerometers on all the cars, displacement transducers on the car suspensions and on the crush zones, strain gages at selected locations, and high- and conventional-speed cameras.

Occupant experiments were included as part of the trainto-train test of CEM equipment. The interior configurations tested included facing seats with an intermediate table, forward-facing commuter seats, and rear-facing commuter seats. All of these interior configurations included features to increase occupant protection over conventional designs. A companion paper describes the results of the occupant experiments [19].

\section{EQUIPMENT TESTED}

Figure 4 shows the FRA prototype cab end crush zone design that was developed as part of the research. The cab end crush zone includes four key elements:

1. A deformable anti-climber arrangement

2. A pushback coupler mechanism

3. An integrated end frame, which incorporates an operator compartment

4. Roof and primary energy absorbing elements

A similar design was developed for non-cab end crush zones. The non-cab end design does not include the deformable anticlimber or incorporate the operator's compartment. The pushback coupler of the non-cab end crush zone has a shorter stroke than the cab end crush zone. The pushback coupler of the cab end crush zone was designed with sufficient stroke to accommodate an impact with a conventional cab car or locomotive.

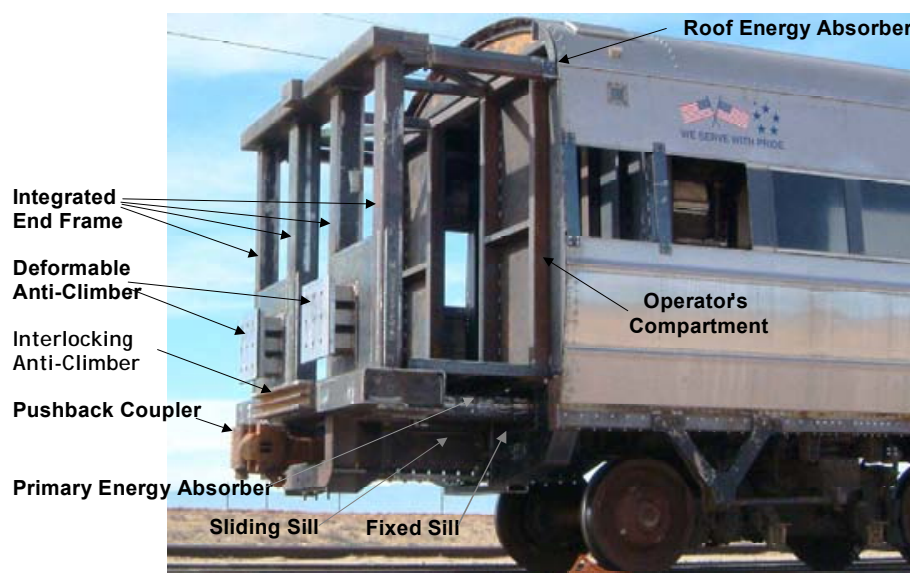

Figure 4. Cab End Crush Zone

The activation of the pushback coupler initiates the crush zone and provides a mechanism that allows each component to operate in sequence. When the coupler triggers and pushes back, an energy-absorbing element crushes. The travel of the shear-back mechanism accommodates the coupler of the impacting equipment to the extent necessary for the anticlimber and integrated end frame to engage the impacting equipment appropriately.

As the anti-climber begins to deform, it accommodates the geometry of the locomotive and distributes the load over as large an area on the integrated end frame as can be reasonably achieved. As a goal, the collision posts should carry 60 percent of the crushable anti-climber loads and the corner posts 40 percent. The anti-climber is designed to crush in a controlled manner and must avoid forming a ramp or a catapult by limiting the potential for material failure. The anti-climber must sustain off-center impact loads and be able to transmit longitudinal loads into the end frame.

The integrated end frame is designed to remain sufficiently stiff in transmitting the impact load to the energy absorbers to assure the proper functioning of these elements. The integrated end frame can appropriately trigger and allow crushing of the energy absorbers when the coupler and the anti-climber share the impact load, or when the load path is through only the coupler or the crushable anti-climber. The structure attached for assuring survival volume of the operator can be pushed straight back into space normally designated for electrical and/or brake service closets. The expected structural deformation does not interfere with ready egress from the operator's compartment before and after the design crush zone stroke has been exhausted. The structure allows for the operator's seat to be attached with sufficient security to remain attached during the test. (Means of protecting the operator from the expected decelerations are currently being explored, including the use of inflatable structures [20].)

When the integrated end frame is subject to a high-energy impact load, the cab end crush zone deforms in a controlled manner, activating the roof and primary energy absorbers. The energy absorbers are able to properly function while accommodating deflections of the integrated end frame. These devices can absorb more than 2 million foot-pounds of energy.

A conventional carbody structure between the two body bolsters (i.e., the underfloor structures at each end of the car that provide support for the suspension) is sufficient to support the loads from the cab end crush zone as it crushes over its design stroke.

Five passenger cars were modified with crush zones for the train-to-train test of CEM equipment. The Pioneer cars tested in the single-car [15] and two-car test [17] of CEM equipment were repaired and used again in the train-to-train test. The previously tested non-cab end crush zone design was adapted to the M1 car, and non-cab end car crush zones were retrofitted onto both ends of one M1 car. Two additional M1 cars had a cab end crush zone on one end and non-cab end crush zone on the other end. 


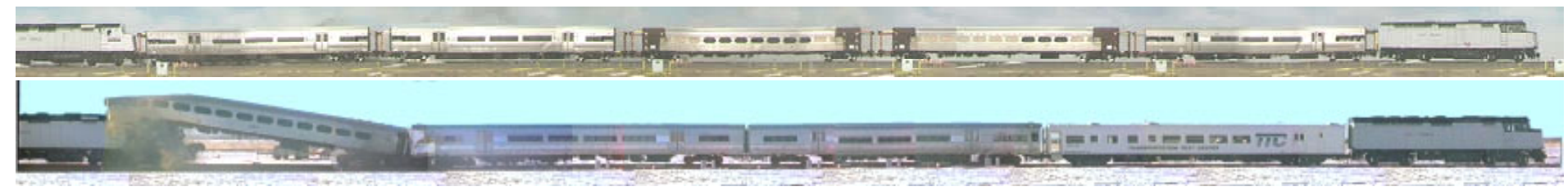

Figure 5. Photographs of Crush Distribution in Train-to-Train Tests of Conventional (lower) and CEM Equipment (upper)

\section{SELECTED TEST RESULTS}

Measurements were made of the overall train collision dynamics during the impact. The train behavior is dependent on the response of the crush zones-the kinematics and the force/crush characteristic. The behavior of the crush zones in turn is dependent on the proper functioning of the components and features that make up the crush zone.

One-dimensional and three-dimensional collision dynamics models were developed before the test to estimate the crush distribution and the gross motions of each of the cars in the two trains. The lumped-mass model uses non-linear spring characteristics to represent the crush response of each car end during a collision (see Figure 2). The current estimate, based upon the design and crush model of the cab end crush zone force/crush characteristic was used for the two crush zones contacting locomotive ends. The force/crush characteristic developed and measured for the non-cab end crush zone $[15,17]$ was used as the crush behavior for all other non-cab end crush zones. The locomotives were assumed to have less than 2 inches of deformation for the collision conditions and are modeled as linear springs with great stiffness.

\section{Train-Level Results}

The key measurements of train collision dynamics include the preservation or loss of operator and passenger volume, the interaction of the colliding and coupled equipment, and the distribution of crush among the passenger cars in the cab carled train.

Figure 5 shows results from the train-to-train tests of conventional and CEM equipment. In the train-to-train test of conventional equipment, the impacted end of the leading cab car crushed by approximately 22 feet, and the impact end of the leading locomotive sustained minor structural damage. No other structural damage was observed in the trailing passenger cars of the train. The cab car overrode the locomotive during the test. The force/crush characteristic of conventional passenger cars prevents the distribution of crush to successive cars. After a single high peak load is exceeded, the car continues to crush at a relatively low uniform load. With the buckling of the primary longitudinal structural support, the draft sill progressed into ramp formation, which initiated override of the locomotive by the cab car (despite the cab car underframe beginning substantially lower than the locomotive underframe).

During the test of CEM equipment, all of the trailing equipment, as well as the impact cab car, sustained structural crush. The operator and passenger space was preserved. The initial kinetic energy of the collision was 20.5 million ft-lbs. Each crush zone is designed to absorb at least 2.5 million $\mathrm{ft}$ lbs. Approximately 14 feet of crush was distributed among the crush zones. By deducting the stroke of the pushback couplers from the total crush, the total shortening of the cars or loss of space in the train is 5.7 feet. Overall, the energy of the collision was successfully managed.

Figure 6 shows the crush distribution for the cars in the CEM consist. Crush is shown at the lead end of the cab car and summed at each successive coupled interface. The test data represent the measurements of the string potentiometers for total stroke of a crush zone (i.e., the stroke of the pushback coupler and the carbody energy absorbers). The plot in Figure 6 compares these measurements with the pre-test collision dynamics model results.

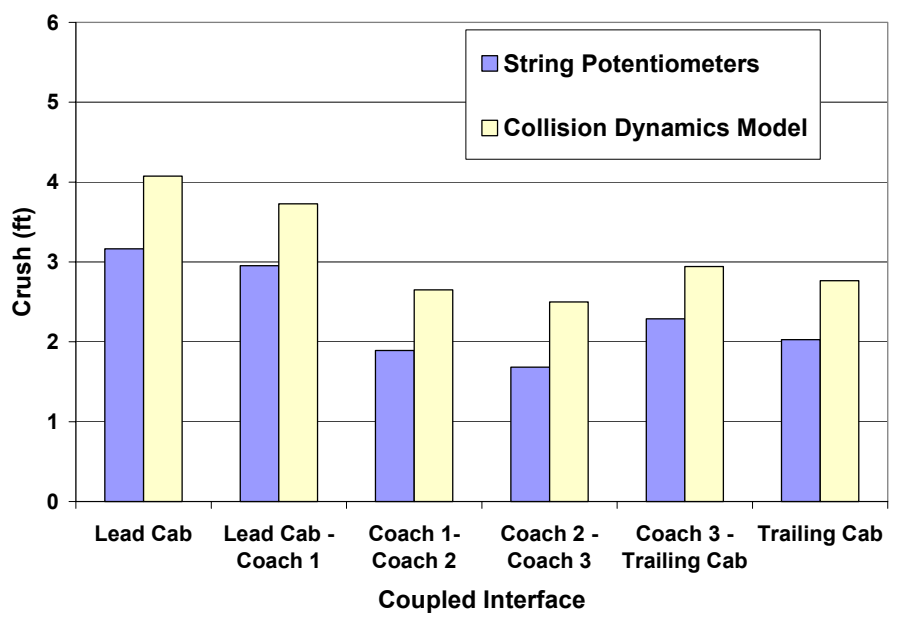

Figure 6. Train-to-Train Test Crush Distribution (Summed at Coupled Interfaces)

The pushback couplers and sliding sills were triggered in every crush zone. The crush zone of the lead cab car came closest to being exhausted, but no crush zone was completely exhausted. The residual crush in each crush zone allows for the CEM system to be effective in a variety of collision scenarios.

The crush distribution plot in Figure 6 shows how the crush was shared between the crush zones of the CEM consist. At the 30.8 mph impact speed, the crush zone of the lead cab car is crushed the most; crush is passed back to the following crush zones. Each car in the CEM system is characterized by an increasing, stepped force/crush behavior. When the force level on the first crush zone reaches the second step, and the primary energy absorbers crush, force levels also begin to be passed to the successive cars, causing those crush zones to trigger. Because the pushback couplers trigger at a lower load than the primary energy absorbers, crush is distributed to additional crush zones before the third peak load level is exceeded at the lead crush zone. 
The pre-test collision dynamics model captures the trend of crush distribution, but it consistently overestimates the total crush at each interface. This difference is attributed to the material properties assumed for the primary energy absorbers. The crush zones manufactured for the single-car and two-car tests of CEM equipment were a batch of steel different from the 10 crush zones manufactured for the train-to-train test. When a sample was tested, the material properties were found to be about 10 percent higher than the material specification. Accordingly, the average crush load of the primary energy absorbers would be higher than estimated by the idealized force/crush curves developed from the previous full-scale testing. Correspondingly, the amount of crush of the energy absorbers required to absorb a set amount of energy decreases with an increased average crush load.

Figure 7 shows the overlay of the test and model results for the velocity-time histories of each vehicle in the CEM passenger consist and the lead locomotive of the initially stationary freight consist. The red traces are the test measurements calculated from the accelerometers at the center of gravity of each vehicle. The blue traces are the corresponding model results. As the lead car impacts the freight consist and begins to crush, it slows rapidly. As the impact load travels through the passenger consist, each crush zone progressively triggers and crushes at a similar load, causing each successive car to slow down at a similar rate to the first car. The velocity trace of the initially standing locomotive is representative of the standing consist, as it sustained no damage during the train-to-train test and essentially moved as a single mass. The model predictions agree with the test results, showing that by 0.75 seconds, all crush is complete, and the passenger and freight consists are moving together down the tracks at approximately $15 \mathrm{mph}$. The differential between each car's post-collision velocity seen in the test data is associated with the uncoupling of the cars. The corresponding conventional test took nearly 2 seconds for the crushing to complete and the two consists to reach the same speed [18].

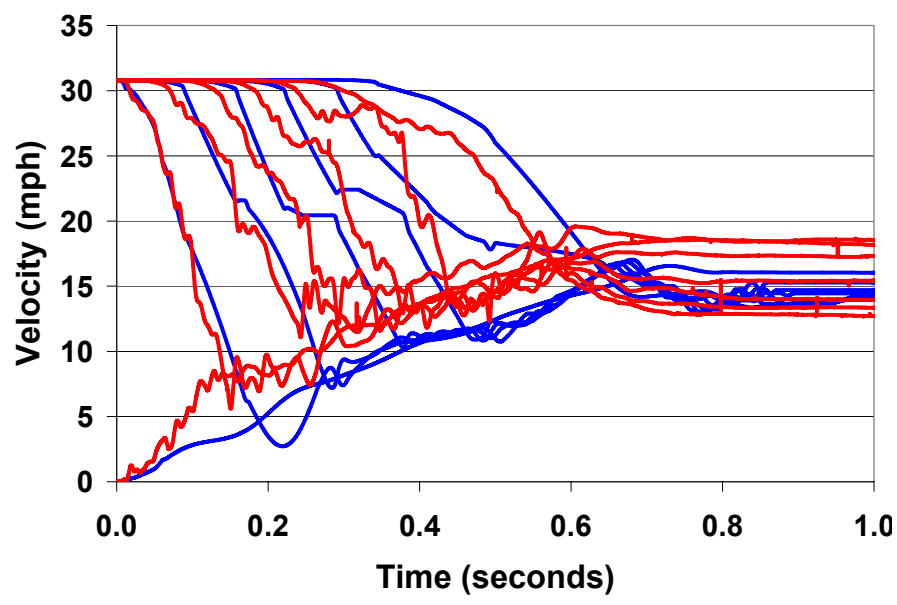

Figure 7. Velocity-Time Histories

Figure 8 shows a plot of the secondary impact velocities (SIVs) in the passenger train. Secondary impact refers to the impact between the occupant and some part of the interior, usually the forward seat, table, or bulkhead. SIV is the relative velocity difference between the occupant and the rail car itself when the occupant strikes the interior. Generally, higher SIVs correlate with increased injury risk, depending on the details of what the occupant strikes. The SIV gives an initial indication of the relative severity of the occupant environment.

In Figure 8, the red traces show the data processed from the accelerometers, and the blue traces indicate the corresponding model results. The test data is computed from the same accelerometers as used for the velocity-time histories in Figure 7. The model results fall within the expected ranges predicted for the cab car and following passenger cars. The secondary impact plot is shown out to 2 feet of travel distance. During a collision, typical commuter seats allow a free-flight distance of 2 feet.

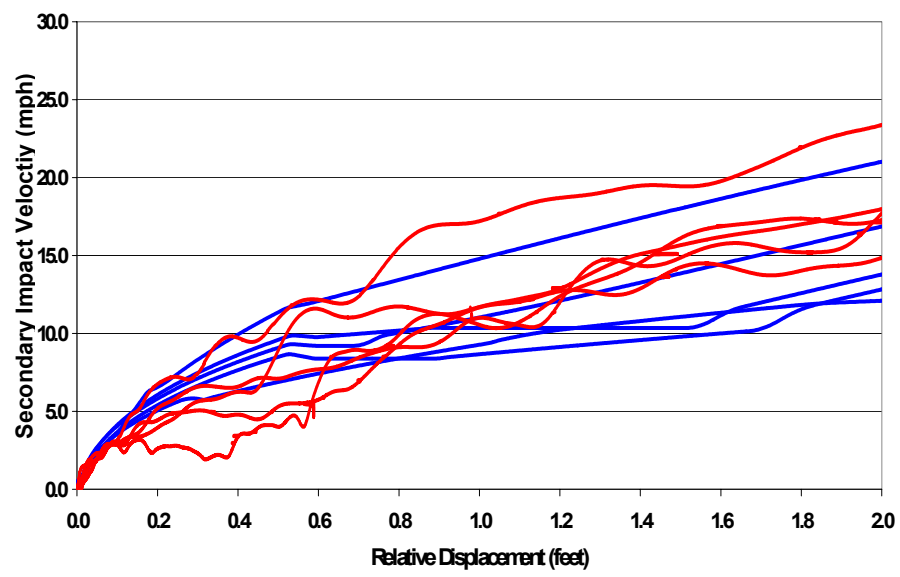

Figure 8. SIV Comparisons

Figure 7 shows that upon impact with the standing consist, the cab car decelerates at the highest rate in the passenger consist. The SIV in Figure 8 verifies that the cab car experiences a more severe occupant environment than the successive cars. A more detailed evaluation of the interior environment and the occupant experiments conducted during the CEM train-totrain test is presented in a complementary paper [19]. This paper discusses strategies for mitigating the more severe occupant environment of the CEM cab car.

\section{Car-Level Results}

The principal functions of the cab and non-cab crush zones are to deform in a controlled manner while providing the appropriate force/crush characteristics to distribute crush appropriately. For the cab end crush zone, deforming in a controlled manner includes managing the impact interface to prevent override. Three types of car-to-car interfaces were in the test: the colliding interface between the impacting cab car and locomotive, the coupled interfaces between passenger cars, and the coupled interface between the last passenger car and the trailing locomotive. Figure 9 is comprised of frames taken from a high-speed movie of the interaction of the impacting cab car and locomotive. These frames show the kinematics of the cab end crush zone as it impacts the standing conventional locomotive. The couplers initially met in state 1 . The stroke of the draft gear was eventually exhausted; the load 
increased on the structural fuse, which then released in state 2 . In state 3 , the deformable anti-climber was engaged, and the load was shared between the anti-climber and the coupler. When the combined load on the coupler and anti-climber was sufficient, the energy absorber structural fuse released in state 4. The primary and roof absorbers crushed and reached state 5 when crush stopped progressing and sufficient energy was absorbed at the impact interface. During the impact, little deformation of the locomotive occurred; in essence the locomotive acted as if it was rigid.

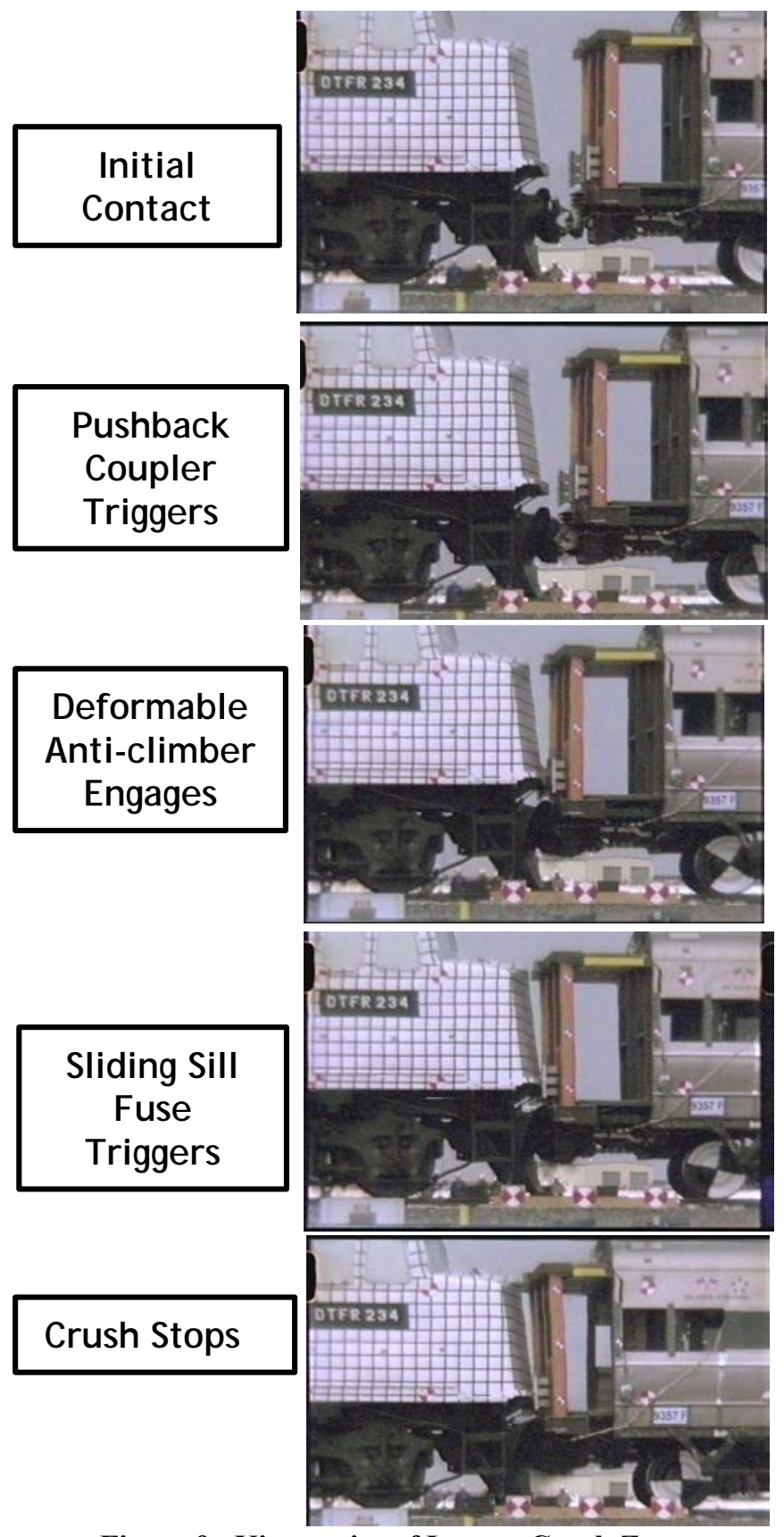

Figure 9. Kinematics of Impact Crush Zone

Figure 10 is comprised of frames taken from a high-speed movie of the interaction of two coupled passenger cars. These frames are representative of the kinematics of all of the coupled passenger car interfaces. The cars were initially coupled in state 1 . The stroke of the draft gear was eventually exhausted; the load increased on the coupler fuse, which then released in state 2 . After sufficient crush of the pushback couplers, the coupled end anti-climbers engaged, and the load was shared between the anti-climbers and the couplers. When the combined load on the coupler and anti-climber was sufficient, the energy absorber structural fuse released in state 3. The primary and roof absorbers crushed, and reached state 4 when crush stopped progressing and sufficient energy had been absorbed at the coupled interface.

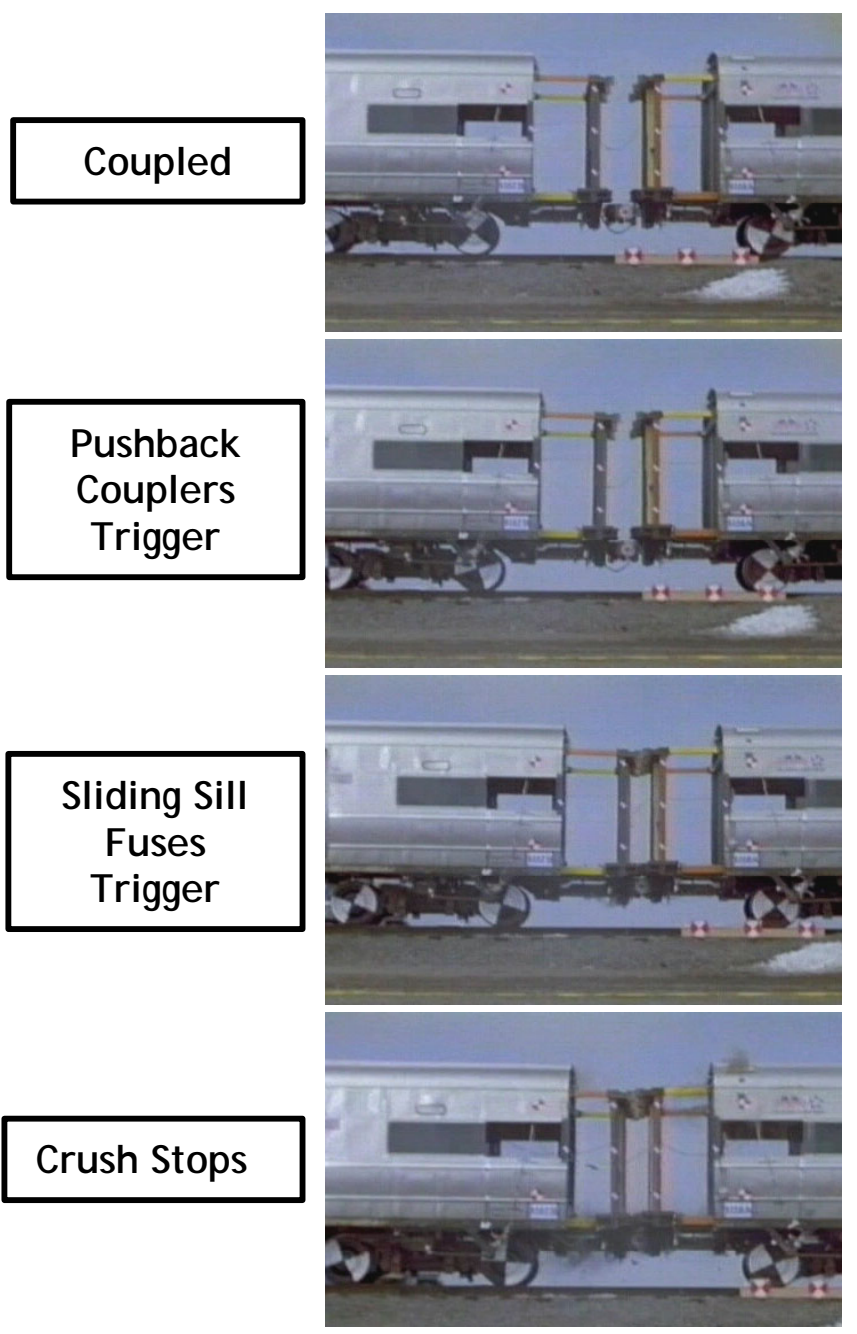

Figure 10. Kinematics of Coupled Non-Cab Crush Zones

Figure 11 shows the kinematics of the trailing cab end crush zone coupled with the trailing conventional locomotive. The frames are from a high-speed movie taken with a camera mounted on board the trailing cab car. The cab car had a pushback coupler, while the locomotive had a conventional coupler arrangement. Since it was a cab end crush zone, the pushback coupler had sufficient stroke to accommodate a conventional coupler while allowing the ends of the coupled equipment to come together. The first frame shows this coupled interface shortly before the impact. The middle frame shows the interface shortly after the pushback coupler has triggered. As can be seen in the middle frame, the centerlines of the cab car and locomotive are offset by about 4 inches. 
This offset grew from the initial impact until the pushback coupler shear bolts triggered. Once the shear bolts triggered, the offset remained but did not continue to grow. After the cab car and locomotive ends came together, the locomotive end began to crush in an uncontrolled manner. The uncontrolled crush increased the relative lateral displacement of the locomotive and the cab car. In addition, the uncontrolled crush of the locomotive caused the end of the locomotive to rise and the end of the cab car to be pushed down. This motion did not progress to override, but the associated vertical load was sufficient to cause a crack near the back of the end beam and the front of the sliding sill. The details of the conditions that led to this crack are currently being investigated. It appears that the vertical load imparted by the locomotive significantly exceeded the vertical load that the end beam was designed to support.

The final frame of Figure 11 shows the final position of the locomotive relative to the cab end crush zone at maximum crush. The rear end of the locomotive's skirt initially contacted the deformable anti-climber and the consequent lateral motion caused the locomotive to contact the collision posts. The integrated end frame accommodated this non-ideal loading condition and shed the load into the sliding sill, successfully triggering the sliding sill fuse.

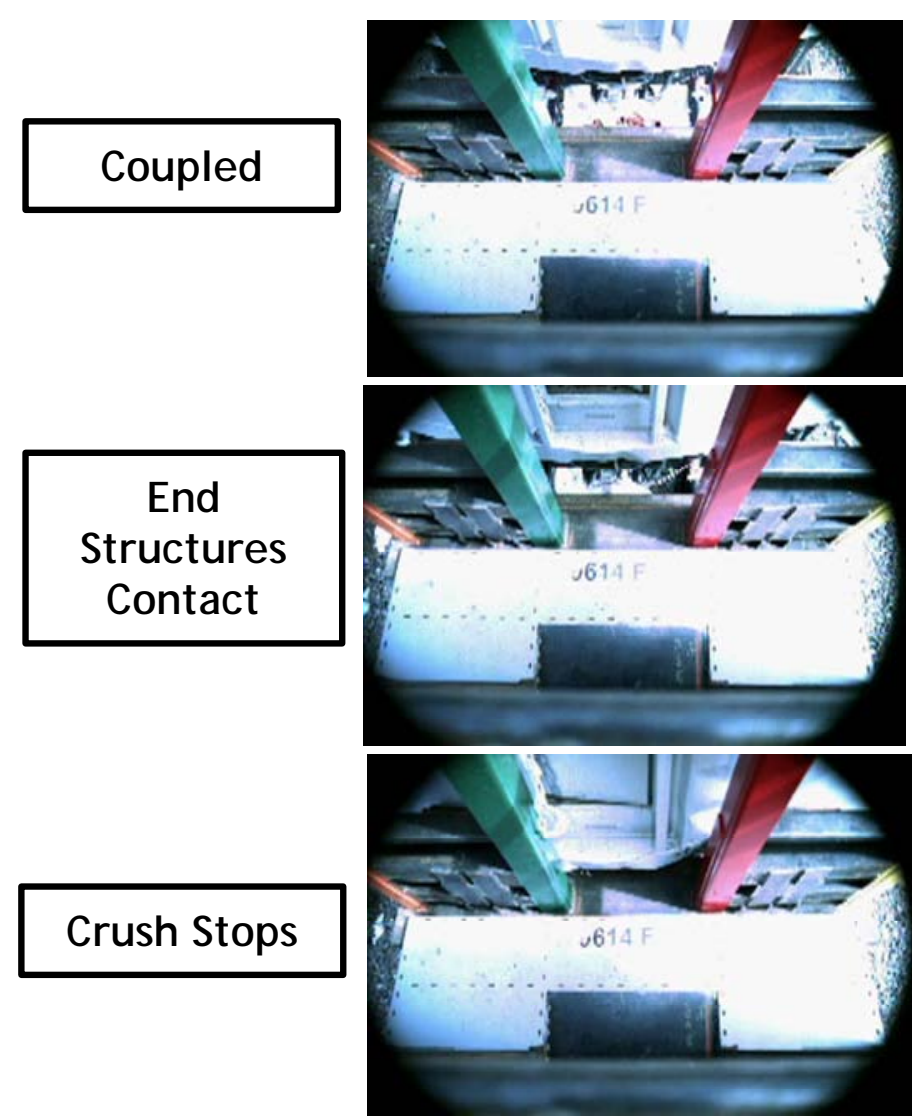

Figure 11. Kinematics of Trailing Cab End Crush Zone and Trailing Locomotive

\section{Component-Level Results}

The cab and non-cab crush zone components functioned as designed. For several of the components, the test results suggest that the form of these components could be improved. Alternative designs could be developed that achieve the same function in a more aesthetically pleasing manner.

As shown in Figure 12, the primary energy absorbers exhibited material failure as a result of the test. This material failure did not influence the function of the energy absorbers during the test-they absorbed energy as intended. However, material failure is difficult to simulate with fidelity, and does increase the uncertainty in analytic predictions of the mode of deformation and the force/crush characteristic of the energy absorber design. For the test equipment, this uncertainty was reduced by prior component, single-car, and two-car tests. A similar level of confidence in the force/crush characteristic of alternative designs may be achieved with fewer tests if material failure is not expected for such designs.

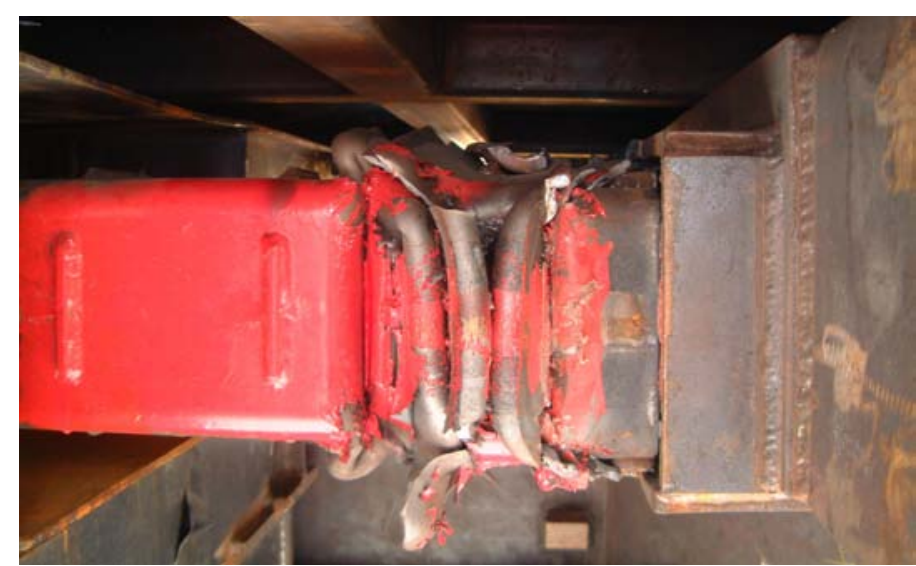

Figure 12. Primary Energy Absorber, Post-Test Photograph Showing Material Failure

The design development and performance of the deformable anti-climber suggests that material failure in the primary energy absorbers can be greatly reduced and potentially eliminated. The deformable anti-climber also performed as designed, and, as shown in Figure 13, deformed as intended without any material failure. The deformable anticlimber was required to be able to support vertical and lateral loads that might arise from the interaction with the colliding locomotive. Consequently, the deformable anti-climber was required to deform without material failure in order to maintain the load path for any vertical and lateral loads. Key differences with the primary energy absorber include thinner, more ductile material, and annealing of the deformable components to relieve residual stresses from forming. Developing primary energy absorbers that incorporate these features would likely result in a design that is not as prone to material failure. 


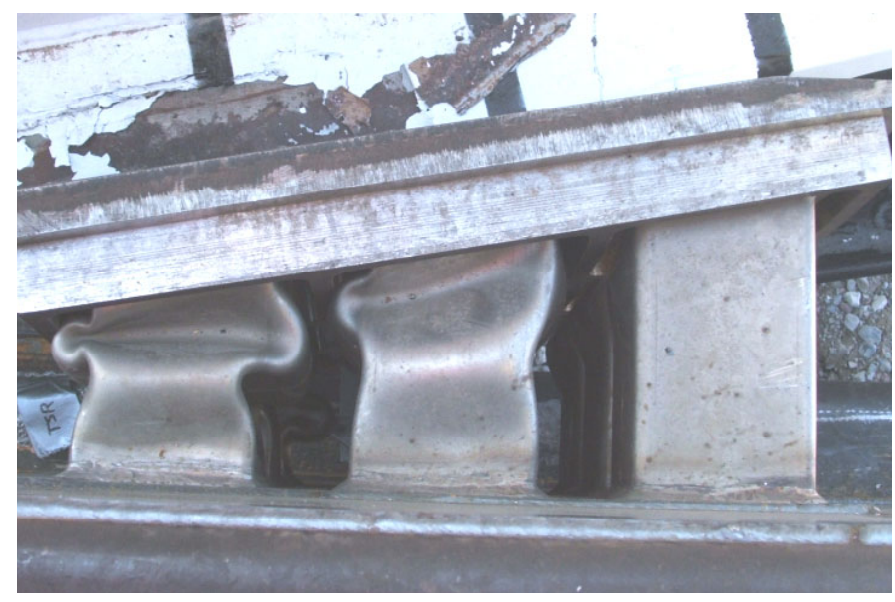

Figure 13. Deformable Anti-climber, Post-Test Photograph Showing No Material Failure

As in some accidents, some of the cars uncoupled during the test. This occurred in the test due to the interaction of the coupler carrier and the coupler pin. As the coupler pushed back, the coupler carrier deformed in such a manner as to push the pin up, releasing the coupler. The couplers functioned as designed as long as there was a buff load between cars. The ability of the cars to remain coupled could be improved by modifying the coupler pin lifting mechanism, the coupler carrier, or some combination. Alternative pin arrangements are currently in service that are less prone to uncoupling than those used in the test.

The side sill of the M1 cars wrinkled during the test. (No visible permanent deformation of the center sills existed after the test.) While no measurable occupant volume was lost, the form could be improved by eliminating the permanent deformation of the side sills. The side sills of the M1 cars are open channel sections. In the area where they wrinkled-just inboard of the reinforcements for the quarter point doorframes-the side sill was not attached to the body sheeting for about 6 inches. Elsewhere on the car, the side sills are spot welded approximately every inch. The wrinkling of the side sill could potentially be eliminated by the addition of more spot welds or by closing the cross section. Either approach would reduce the potential for column buckling.

The operator space was preserved, and there are no obvious improvements in form for the operator's compartment. The end frames for both the cab end and noncab end crush zones performed as intended. These translated the loads applied to the car into the loads required to crush the primary and roof energy absorbers. More detailed inspection of the crush zone and its components is planned.

\section{CONCLUSIONS AND DISCUSSION}

In the train-to-train test of conventional equipment, the space for approximately 47 passengers and the operator was destroyed. Under the same impact conditions, the CEM equipment preserved the space for all of the occupants.

In order to reduce the injury risk to the occupants in this more severe environment, modifications to the interior arrangements are being made to keep secondary impact forces and decelerations within survivable limits. Five experiments were included on the train-to-train impact test of CEM equipment to measure the occupant response in modified versions of previously tested seating arrangements: forwardfacing intercity seats, forward- and rear-facing commuter seats, and facing commuter seats with intervening tables. These modifications minimize the injury risk to the occupants [19].

CEM features can be progressively added to existing equipment to improve crashworthiness incrementally [21]. A conventional cab car-led train of single level equipment with end vestibules can protect all of the occupants in a collision with a locomotive-led train of the same weight for closing speeds up to approximately $15 \mathrm{mph}$. Changing from a conventional cab car to a CEM cab car, such as the cab car used in the test, increases the closing speed to $25 \mathrm{mph}$. Further modifying the trailing cars to include pushback couplers (with conventional carbody structures) increases this closing speed to $28 \mathrm{mph}$. The highest level of crashworthiness is provided by all CEM passenger cars, which can protect all of the occupants for closing speeds up to 38 mph in this scenario.

Further work is needed to evaluate the use of CEM features on locomotives. While the current CEM cab car design accommodates for the features of conventional locomotives, the robustness of a CEM system would be enhanced at the train level by including features such as pushback couplers and deformable anti-climbers on conventional locomotives.

\section{ACKNOWLEDGEMENTS}

The research described in this paper was performed as part of the Equipment Safety Research Program sponsored by the FRA's Office of Research and Development. The authors would like to thank Claire Orth, Chief, Equipment and Operating Practices Division, for her support. Dr. Tom Tsai, Program Manager, led this effort. Gunars Spons, FRA Resident Manager at the Transportation Technology Center, managed the full-scale test effort. Grady Cothen, Deputy Associate Administrator for Safety Standards and Program Development, has coordinated FRA's regulations development and the passenger rail equipment crashworthiness research since the inception of this research.

The authors would also like to thank Volpe Center colleagues Kristine Severson and Daniel Parent for designing and overseeing the implementation of the occupant protection experiments. Michelle Priante, Mechanical Engineer, and Michael Carolan, Mechanical Engineer, assisted in oversight of the test implementation and documentation of the test results.

Matthew Witte, Senior Engineer, led the TTCI team that implemented the test. Tom Roderick, Senior Technician, Joe Hanratty, Senior Technician, and Bruce Perrin, Senior Technician TTCI, integrated the crush zones into the cars. Jay Gordon and Chuck Monson, GMH Engineering, installed much of the instrumentation and acquired all of the data. Jerry MacIntire, CineMac Productions, filmed the high-speed movies of the test. 
METROLINK, the Los Angeles commuter railroad, in their ongoing procurement of passenger rail equipment, has applied the results of the research into Crash Energy Management. Jo Strang, Associate Administrator for Safety, FRA, led an ad hoc CEM Working Group, which was formed with FTA, APTA, rail industry suppliers, labor organizations, and consultants. This Working Group developed a specification based on the results of this research. The authors would like to thank Associate Administrator Strang for coordinating the activities of the Congressional delegation that attended the test.

The authors would also like to thank Paul Feenstra, Public Affairs, Research and Innovative Technology Administration, Steve Kulm, Public Affairs, FRA, and Melissa Cook, Public Affairs, Office of the Secretary of Transportation, for their tireless efforts in coordinating and disseminating information on the test to the media, as well as for their efforts to coordinate the attendance of the Secretary of Transportation, Norman Mineta. The authors would like to thank Secretary Mineta for his attendance and interest in the test.

\section{REFERENCES}

[1] Cothen, G., Schulte, C., Horn, J., Tyrell, D., "Consensus Rulemaking at the Federal Railroad Administration," TR News, Transportation Research Board, Number 236, January-February 2005.

[2] Tyrell, D., "U.S. Rail Equipment Crashworthiness Standards," presented at 'What can We Realistically Expect from Crashworthiness?' Rail Equipment Crashworthiness Symposium, Institute of Mechanical Engineers, May 2, 2001, London, England.

[3] U.S. Department of Transportation, Federal Railroad Administration, "49 CFR Part 216 et al., Passenger Equipment Safety Standards; Final Rule," Federal Register, May 12, 1999.

[4] Tyrell, D.C., Severson, K.J., Marquis, B.J., "Crashworthiness of Passenger Trains," U.S. Department of Transportation, DOT/FRA/ORD-97/10, 1998.

[5] Tyrell, D., Martinez, E., Jacobsen, K., Parent, D., Severson, K., Priante, M., Perlman, A.B., "Overview of a Crash Energy Management Specification for Passenger Rail Equipment," American Society of Mechanical Engineers, Paper No. JRC2006-94044, April 2006.

[6] American Public Transportation Association, Member Services Department, Manual of Standards and Recommended Practices for Passenger Rail Equipment, Issue of May 1, 2004.

[7] Association of American Railroads, Technical Services Division, Mechanical Section-Manual of Standards and Recommended Practices, "Locomotive Crashworthiness Requirements, Standard S-580," Adopted 1989, Revised 1994, Revised 2005.

[8] Mayville, R., Johnson, K., Tyrell, D., Stringfellow, R., "Rail Vehicle Car Cab Collision and Corner Post Designs According to APTA S-034 Requirements," American Society of Mechanical Engineers, Paper No. MECE2003-44114, November 2003.

[9] Martinez, E., Tyrell, D., Rancatore, R., Stringfellow, R., Amar, G., "A Crush Zone Design for An Existing Passenger Rail Cab Car," American Society of Mechanical Engineers, Paper No. IMECE200582769, November 2005.

[10] Mayville, R.A., Stringfellow, R.G., Rancatore, R.J., Hosmer, T.P., "Locomotive Crashworthiness Research, Volumes 5: Cab Car Crashworthiness Report” DOT/FRA/ORD-95/08.5, 1996.
[11] Tyrell, D.C., Severson, K.J., Mayville, R.A., Stringfellow, R.G., Berry, S., Perlman, A.B., "Evaluation of Cab Car Crashworthiness Design Modifications," Proceedings of the 1997 IEEE/ASME Joint Railroad Conference, Institute of Electrical and Electronics Engineers, Catalog Number 97CH36047, 1997.

[12] Stringfellow, R.G., Mayville, R.A., Rancatore R., "A Numerical Evaluation of Protection Strategies for Railroad Cab Car Crashworthiness," American Society of Mechanical Engineers, AMD Vol. 237/BED Vol. 45, 1999.

[13] Tyrell, D.C., Perlman, A.B., "Evaluation of Rail Passenger Equipment Crashworthiness Strategies," Transportation Research Record No. 1825, pp. 8-14, National Academy Press, 2003.

[14] Tyrell, D., Severson, K., Perlman, A.B., "Single Passenger Rail Car Impact Test Volume I: Overview and Selected Results," U.S. Department of Transportation, DOT/FRA/ORD-00/02.1, March 2000.

[15] Jacobsen, K., Tyrell, D., Perlman, A.B., "Impact Test of a Crash Energy Management Passenger Rail Car," American Society of Mechanical Engineers, Paper No. RTD2004-66045, April 2004.

[16] Tyrell, D., Severson, K., Zolock, J., Perlman, A.B., "Passenger Rail Two-Car Impact Test Volume I: Overview and Selected Results," U.S. Department of Transportation, DOT/FRA/ORD01/22.I, January 2002.

[17] Jacobsen, K., Tyrell, D., Perlman, A.B., "Impact Tests of Crash Energy Management Passenger Rail Cars: Analysis and Structural Measurements," American Society of Mechanical Engineers, Paper No. IMECE2004-61252, November 2004.

[18] Tyrell, D., "Passenger Rail Train-to-Train Impact Test Volume I: Overview and Selected Results," U.S. Department of Transportation, DOT/FRA/ORD-03/17.I, July 2003.

[19] Severson, K., Parent, D., “Train-to-Train Impact Test of Crash Energy Management Passenger Rail Equipment: Occupant Experiments," American Society of Mechanical Engineers, Paper No. IMECE2006-14420, November 2006.

[20] Zolock, J., Tyrell, D., "Locomotive Cab Occupant Protection," American Society of Mechanical Engineers, Paper No. IMECE200344121, November 2003.

[21] Jacobsen, K., Severson, K., Perlman, A.B., "Effectiveness of Alternative Rail Passenger Equipment Crashworthiness Strategies," American Society of Mechanical Engineers, Paper No. JRC200694043, April 2006. 